\title{
Research on the School-Enterprise Modern Apprentice Talent Training Model of Logistics Management Specialty in Higher Vocational Education*
}

\author{
Shijun Yuan \\ Hunan Modern Logistics College \\ Changsha, China 410131
}

\begin{abstract}
At present, the school-enterprise cooperation in the cultivation of high-skilled personnel in higher vocational logistics management is in the exploratory stage, and some higher vocational colleges fail to closely follow the characteristics of logistics management professions, fail to establish the school-enterprise integrated education training mode and its supporting mechanism. Hunan Modern Logistics College fully docks with the development of the logistics industry, is deeply integrated into the industrial chain of Hunan regional economic development, carries out in-depth cooperation between schools and enterprises, and actively explores the modern apprenticeship training model for logistics management majors in higher vocational education, so as to promote the development of logistics higher vocational education.
\end{abstract}

Keywords-logistics management; modern apprenticeship; talent training mode

\section{INTRODUCTION}

The "modern apprenticeship" is essentially a modern vocational education system in which industry and education are deeply integrated, schools and enterprises jointly educate people, and school education is closely combined with vocational training. The training of logistics management talents under the modern apprenticeship system should be aligned with the professional standards of logistics management. Supported and guaranteed by policies, laws, and institutions, the modern apprenticeship system in developed western countries has played an active role in the cultivation of high-skilled talents needed in their economic transition. At present, China is also in a critical period of economic transformation that urgently needs a large number of highly skilled talents. The introduction and practice of modern apprenticeship is the key to solving China's cultivation of high-skilled talents at this stage.

*Fund: It is supported by the phased research results of 2018 Annual Project of Hunan Provincial Education Science "Thirteenth Five-Year Plan" - Study on the collaboration management mechanism based on "dual subjects and dual identities" (XJK18BZY042).

\section{STATUS QuO AND DifFICULTIES OF TRAINING TALENTS IN LOGISTICS MANAGEMENT IN HIGHER VOCATIONAL COLLEGES}

Now, the school-enterprise cooperation in the cultivation of high-skilled personnel in higher vocational logistics management is in the exploratory stage, and some higher vocational colleges fail to closely follow the characteristics of logistics management professions, fail to establish the school-enterprise integrated education training mode and its supporting mechanism. And it is mainly shown in the following concepts.

\section{A. The Training Objectives and Social Needs Doesn't Achieve Seamless Integration}

At present, the degree of vocational logistics management talents training doesn't match with the real needs of logistics industry and enterprises for talents. As a result, the professional curriculum system, specific teaching contents and practical training in and out of the school are deviated from the actual demand of the post corresponding to the logistics industry and enterprises to a certain extent. The cultivated students can't well adapt to the social demand, and there is the phenomenon of mismatch between supply and demand.

\section{B. Formalization of Reform of Talent Training Mode}

The talent training model of logistics management major is different from that of science and engineering major. It is mainly reflected in the following aspects. Firstly, the basic and middle-level and senior management positions of logistics management are not like the production line of a production company, which can arrange a large number of students to conduct internship training. Companies are also concerned about the impact of a large number of students on the normal business activities of their enterprises, and generally refuse to accept students' internship. It faces obstacles in the implementation of on-the-job practice and training. Schools generally carry out on-campus practice. The visits and learning in enterprise, short-term on-job 
practice and other practical training make the reform of logistics management personnel training mode a formality. Secondly, the talent training of logistics management is open, and it needs to be familiar with and understand the logistics operation process, be able to operate, and understand the management. Therefore, the short-term practice is difficult to achieve the expected goal of talent training.

\section{Shallow Cooperation Between School and Enterprise}

Now, the mode of school-enterprise cooperation in logistics management in higher vocational colleges is relatively single. The content forms mainly focus on shallow cooperation such as order training and the development of related professional courses and teaching materials. And the breadth and depth of cooperation forms need to be further strengthened.

\section{The Construction of a "Double-tutor" Teacher Team Needs to Be Strengthened}

At present, most teachers in higher vocational colleges are from the colleges and universities. They have rich professional theoretical knowledge and classroom teaching experience, and relatively lack practical experience in enterprises. Although the colleges also pay attention to the construction of a "double-tutor" teacher team and encourage professional teachers to participate in training to obtain qualification certificates, short-term training for professional teachers to improve the practical ability is still limited, and it is not realistic to stay in the company for a long time to have the on-the-job practice.

\section{REFORM GOALS OF THE MODERN APPRENTICESHIP TRAINING MODEL IN LOGISTICS MANAGEMENT}

It is required to comprehensively dock the development of logistics industry, deeply integrate into the Hunan regional economic development industrial chain, build a middle-level and senior talent training chain, and improve the flexible order-form training mechanism that is close to the industry and the market, stabilizing the professional group order ratio at $30 \%$. It is possible to promote the apprenticeship and Sino-German cooperation in running schools, expand the scale of training, and transform the training of talents from orders and customized training to Sino-foreign joint and standardized system training. Eventually, it will form a professional group talent training model of "schoolenterprise integration, Sino-foreign integration". In short, it is necessary to make efforts to improve the talent training level of the entire Hunan modern logistics management professional group.

The college should optimize the construction of the professional group curriculum system, build 5 professional group shared courses, 3 specialty courses, and develop 3 comprehensive high-quality courses and training courses in cooperation with enterprises. It is necessary to improve the curriculum teaching, assessment standards, and training standards, promote informatization teaching, construct shared courses, special micro-lecture or MOOC, build resource integration platforms, and complete the high-quality digital teaching resource bank construction of "three resource sub-bank". It is required to strengthen the construction of practical teaching system, and establish the training base of "enterpriseization, digitization, simulation" on the basis of the integration of industry, learning, research and training. There are projects for courses, bases for all kinds of training, and platforms for joint training, ensuring that the project output rate reaches $100 \%$. The college should further promote the reform of the credit system and the "dual certificate" system to ensure that the double-certificate rate reaches $100 \%$. At the same time, it is necessary to improve the common supervision mechanism for the quality of multisubject personnel training and effectively improve the quality of personnel training.

\section{REFORM AND IMPLEMENTATION OF MODERN APPRENTICESHIP TRAINING MODE FOR LOGISTICS MANAGEMENT MAJOR}

\section{A. Deepening the Reform of the Flexible Order Training Model Based on the Modern Apprenticeship}

On the basis of the talent training model of "responding to the market and flexible order training", the college will strengthen cooperation among industry companies, vocational schools and undergraduates, foreign universities and other parties, continuously deepen the reform of talent training models, and vigorously promote targeted training, joint training, and order training, link up the middle and high school to improve the training of modern apprenticeship talents.

It is required to systematize enterprise standards, assessment standards, and teacher training standards of modern logistics apprenticeship and integrate them into the daily talent training process to form a talent training curriculum system, technical skills system, and assessment system, which are widely used in the flexible order training process. Finally, it can further improve the quality of talent training, and further deepen the flexible order training model based on the modern apprenticeship system.

\section{B. School-Enterprise Cooperation, Dynamic Adjustment and Optimization of Personnel Training Programs}

In accordance with the overall development of the professional group, it is necessary to pay attention to the development of logistics industry-related companies and organizations such as industrial parks, economic and technological development zones, manufacturing enterprises, trade and distribution companies, third-party logistics companies and logistics parks. Aiming at the detailed division of labor in the logistics industry and enterprises, the research on the positions of logistics management professionals and the analysis of talent demand are carried out, so as to master the talent ability, quality and quantity demand of logistics enterprises. Relying on the logistics vocational education group, the Hunan Logistics Industry Development Summit Forum was held to discuss industry development trends and development needs, and to improve the training objectives and positioning of logistics management, engineering logistics, procurement 
management, international shipping business management, and cold chain logistics in the logistics management professional group, dynamic adjustment and optimization of talent training programs. It is convenient to deepen the training of cooperation orders with enterprises, so that talent training can respond to market demands in agile manner.

\section{Grasping the Sino-Foreign Cooperation in Running} Schools, Promoting the Pilot Project of Linking Apprenticeship with Secondary Technical School and Junior College, and Improving the Talent Training Chain

The college will do a good job in the " $3+2 "$ international talent training cooperation project for Sino-German cooperation in logistics management. The college will follow up all the graduates who have gone to Germany for undergraduate studies in the first phase, and train the students at second and third phase. During the three-year construction period, the college will ensure that the number of students in each phase is stable between 30 and 40, introduce the teaching management methods, assessment standards, and school-enterprise cooperation experience of DIPLOMA Fachhochschule Nordhessen, and improve the talent training, curriculum construction, quality supervision, and school-enterprise cooperation, making the content of Sino-foreign cooperation in running schools richer. At the same time, the college can expand the cooperation with DIPLOMA Fachhochschule Nordhessen and Derby University in the professional group, and further expand the Sino-foreign cooperative education and talent training model.

It is required to do a good job in implementing the pilot project of linking apprenticeship with secondary technical school and junior college. At the same time, it is necessary to sum up experience in a timely manner, and make the promotion.

The college should grasp the teaching work of the four stages of basic training, theory and on-campus training, oncampus internship, off-campus internship and on-the-job internship, strengthen the connection between undergraduates and relevant institutions in the fifth stage of international education, and create a good talent training chain for modern logistics management.

\section{Improving the Evaluation Mechanism of Professional Group Construction, and Promoting the Construction of Third-party Quality Evaluation System}

It is required to reform the existing evaluation system, improve the evaluation index system, and integrate the process assessment with the ultimate assessment. The college will improve the quality monitoring and evaluation system of "government, school, enterprise and business" and internal and external integration, so as to realize the diversification of evaluation subjects, contents and methods, and innovate the multi-evaluation system. The college can introduce a third-party authoritative data evaluation organization, and comprehensively track the social needs and training quality of graduates of the modern logistics management professional group through a third-party evaluation organization, follow-up evaluation of school students, and mid-term career development evaluation of graduates. A third-party authoritative data evaluation organization will give an authoritative evaluation report on professional construction and professional competitiveness. At the same time, an online teaching quality evaluation information system is established to improve the efficiency of personnel training quality evaluation and information management by means of information technology.

\section{CONSTRUCTION MEASURES}

The college can establish a steering committee of professional group construction, improve rules and regulations, and carry out daily operations and management.

Based on the supervision office and academic affairs office of the college, it strengthens the construction and implementation of the teaching management system, strengthens the construction, planning, inspection and evaluation of "six networks and one platform", and coordinates the credit system reform.

The personnel office, the school-enterprise office and the logistics management department coordinate to strengthen the construction planning and management of the professional faculty team, and implement the teacher training plan.

It is required to formulate the "Implementation Measures of Target Responsibility System of Hunan Province Demonstrative Characteristic Professional Group Construction of Hunan Modern Logistics College", adopt the "project management" operation mode, implement the "project responsible person" system, strengthen the sense of responsibility, and design the target responsibility system, guarantee that the demonstration specialty construction will be carried out in a self-required and self-monitoring working state from beginning to end. The construction of demonstration specialty groups will be carried out with high standards and high quality.

It is necessary to formulate the "Quality Monitoring and Evaluation System for the Construction of the Demonstrative Characteristic Professional Groups of Hunan Modern Logistic College" and "Reward and Punishment System for the Construction of Exemplary Specialty Groups of Hunan Modern Logistic College", and establish the scientific monitoring and evaluation system and the reward and restraint mechanism. In accordance with the requirements of "monthly arrangements, quarterly inspections, and annual assessments", the college can regularly conduct quality assessments to ensure that the demonstration professional group construction projects can be completed with quality and quantity.

It is possible to formulate the "Administrative Measures for the Construction of Demonstrative Specialized Professional Group Funds of Hunan Modern Logistic College" and the "Administrative Measures for the Financial Budget of Hunan Modern Logistic College", and set up a special fund management leader for the construction of demonstration professional groups, and effectively 
strengthen the use and management of project funds, ensuring that the funds are earmarked. All major construction projects will be subject to public bidding, and they will be inspected, supervised, evaluated, and audited to ensure that the construction of demonstration specialty groups is completed on time and with the required quality and quantity.

\section{CONCLUSION}

With in-depth integration of production and education, schools and enterprises jointly develop modern apprenticeships for higher vocational logistics management majors, adapting to the current development direction of vocational education reform, and meeting the needs of enterprises for modern logistics talents. However, in the development of modern apprenticeship talents, how to establish an effective benefit-sharing mechanism and achieve win-win education ecology among schools, enterprises and apprentices is the key to the sustainable development of this kind of talent training model.

\section{REFERENCES}

[1] Guo Weina. Study on the School-Enterprise Joint Training Path of Logistics Management Talents in Higher Vocational Colleges [J]. Rural Economy and Science and Technology. 2018 (10). (in Chinese)

[2] Li Hong. Construction and Practice of "Logistics Technical Skill Training Chain" for Logistics Management Talents of Higher Vocational Education Against the Background of "Internet +" [J]. Logistics Technology. 2017 (12). (in Chinese)

[3] Miao Aihua. The Research of Logistics Management Personnel Training for Vocatinnal College Students in the Context of Industrial Transferring and Upgrading [J]. Education and Teaching Forum. 2017 (02). (in Chinese) 